Acta Crystallographica Section A

Foundations of Crystallography

ISSN 0108-7673

\section{Prices of IUCr journals}

\section{Prices for 2002}

The subscription rates and prices for back numbers as from 1 January 2002 are given in Table 1.

There will be a $5 \%$ discount on the prices of the individual sections for subscribers taking out combined subscriptions to Sections $A+B+C+D$ and Sections $A+B+C$ of Acta Crystallographica. Individuals may also take out a subscription to Sections $A+B+D$ at a discount of $5 \%$. Subscribers taking out a combined subscription to Journal of Applied Crystallography and Journal of Synchrotron Radiation will receive a discount of $14 \%$.

The reduced-rate (personal) subscriptions are ordinarily only available to members of recognized scientific societies, and applications must be accompanied by a written undertaking that the journal is for the personal use of the subscriber and will not be made available to libraries, institutions etc. These conditions also apply to persons wishing to order back numbers at the reduced rates.

Volumes and single printed parts of each journal for the last five years are available at the same cost as volumes and single parts of that journal in 2002.

\section{Crystallography Journals Online}

Electronic editions of all IUCr journals will be available online in 2002 from Crystallography Journals Online via the following addresses:

Acta Crystallographica Section A: Foundations of Crystallography, http://journals.iucr.org/a/journalhomepage.html

Acta Crystallographica Section B: Structural Science, http://journals.iucr.org/b/journalhomepage.html

Acta Crystallographica Section C: Crystal Structure Communications, http://journals.iucr.org/c/journalhomepage.html

Acta Crystallographica Section D: Biological Crystallography, http://journals.iucr.org/d/journalhomepage.html

Acta Crystallographica Section E: Structure Reports Online, http://journals.iucr.org/e/journalhomepage.html

Journal of Applied Crystallography,

http://journals.iucr.org/j/journalhomepage.html

Journal of Synchrotron Radiation,

http://journals.iucr.org/s/journalhomepage.html

Subscribers to print editions will have full access to online versions of the journals at no extra charge. Online-only access is available at $90 \%$ of the print + online subscription price.

Table 1

Institutional and personal subscription price information for IUCr journals for 2002.

Prices are inclusive of postage (airfreight). All print subscriptions come with free online access.

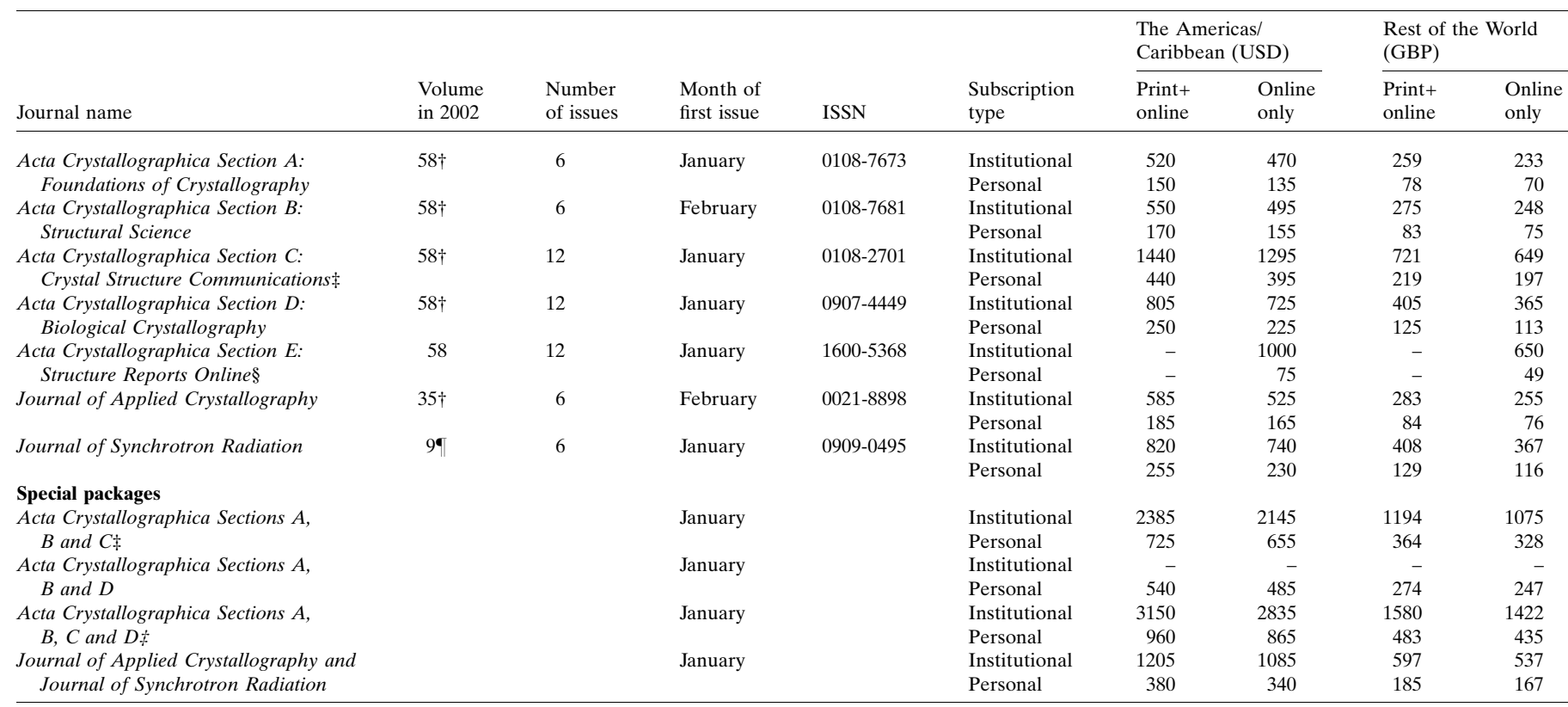

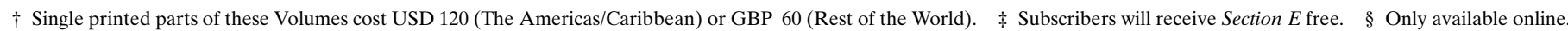
Free to subscribers to Section C. S Single printed parts of this Volume cost USD 150 (The Americas/Caribbean) or GBP 75 (Rest of the World). 


\section{international union of crystallography}

A number of services, including tables of contents, e-mail alerting and the provision of supplementary material, remain free of charge to both subscribers and nonsubscribers. In addition, both subscribers and nonsubscribers will retain access to full texts of certain types of article (e.g. CIF Applications, Letters to the Editor, Book Reviews) and to some individual articles of other types.

\section{Multisite access and consortia}

Academic institutions with more than one geographical site will be granted access to Crystallography Journals Online from multiple sites for 2002. There will be no extra charge provided that the total number of subscriptions held by the institution is maintained at the levels existing in 2001.

Commercial organizations wishing to access the service from multiple sites should contact subscriptions@iucr.org or visit http:// journals.iucr.org/services/subscriberservices.html for more details. The IUCr will be pleased to negotiate global access arrangements for commercial organizations.

The IUCr currently has package deals available for consortia; for details contact subscriptions@iucr.org.

\section{Licences}

Subscribers will be granted access to the online editions of IUCr journals in 2002 without a licence. However, subscribers will be asked to read the current Terms and Conditions of Use of Crystallography Journals Online before registering for the service.

\section{Back-issues policy}

Crystallography Journals Online provides electronic editions of the full back catalogue of IUCr journals (from 1948 to date). This backissue archive consists of over 50000 articles and 200000 pages.

Subscribers holding a current subscription to a particular journal will have access to all back issues of that journal. Individual articles from the back-issue archive will also be available to nonsubscribers on payment of a fee for each individual article.

\section{Archiving}

The IUCr has prepared a statement on its long-term archiving policy. This is available from http://journals.iucr.org/ services/subscriberservices.html.

\section{Orders}

Orders for print and online editions of Acta Crystallographica, Journal of Applied Crystallography and Journal of Synchrotron Radiation may be addressed to Customer Services Department, Blackwell Publishing, PO Box 805, 108 Cowley Road, Oxford OX4 1FH, UK (e-mail: jnlinfo@blackwellpublishers.co.uk). Orders from subscribers in North America may alternatively be placed through Polycrystal Book Service, 895 Martin Road SW, Huntsville, AL 35824, USA (e-mail: polycbs@polycbs.com; WWW: http://www. polycbs.com). 